\title{
GENETIC PROGRESS IN 20 YEARS OF RECIPROCAL RECURRENT SELECTION IN MAIZE
}

José Arantes Ferreira Júnior ${ }^{1}$, Gabriel Moreno Bernardo Gonçalves ${ }^{1}$, Jocarla Ambrosim Crevelari ${ }^{1}$, Yure Pequeno de Souza ${ }^{1}$, Vivane Mirian Lanhellas Gonçalves ${ }^{1}$, Flávia Nicácio Viana ${ }^{1}$, Julio Cesar

FiorioVettorazzi $^{1}$, Messias Gonzaga Pereira ${ }^{1}$ 1) Laboratório de Melhoramento Genético Vegetal, Universidade Estadual do Norte Fluminense Darcy Ribeiro (UENF),
Campos dos Goytacazes, RJ, Brazil.

*Corresponding author: Gabriel Moreno Bernardo Gonçalves (gabriel.agrobio@gmail.com)

Abstract: Maize, a grain distinguished globally for its economic relevance, has experienced a large increase in yield in the past decades. Breeding programs, which are largely responsible for crop development, aim at using techniques that maximize profits and are in accordance with local demand. The full-sib reciprocal recurrent selection (RRS) has a long-term focus on producing better performing hybrids. On this basis, this study intended to evaluate the development of reciprocal populations (Piranão and CIMMYT) throughout ten RRS cycles, in terms of genetic progress, and to verify the occurrence of heterosis and its magnitude. To this end, each of the ten selection cycles, represented by three genotypes (Piranão genotypes, CIMMYT genotypes, and interpopulation hybrids) were tested in four trials, in two locations, and in two years, in a 14×20 alpha-lattice with four replicates. The traits evaluated were grain yield, ear weight, and prolificacy. There was a major increase for all traits in interpopulation hybrids, even though the CIMMYT parent had not shown a significant increase, suggesting that even though one of the populations stagnates after 10 cycles, RRS is efficient in obtaining superior hybrids. There was an average increase of $171 \mathrm{~kg} \cdot \mathrm{ha}^{-1} \cdot$ cycle $^{-1}$ throughout the ten cycles. Heterosis and heterobeltiosis oscillated between cycles, with higher mean for heterosis, suggesting discrepancy between the parents and superiority of the Piranão population (possibility to indicate the increase in yield per cycle or per year).

Keywords: Zea mays, plant breeding, heterosis, genetic gain, alpha-lattice. 


\section{Introduction}

Maize (Zea mays L.) plays a prominent role on the global scenario, as it is not only the most widely grown grain in the world, but also one of the basic ingredients in the diet of several peoples. It is used intensively in animal feed production, intended mainly for poultry and pigs, in the processing industry, and it is currently the raw material for ethanol production (Moro and Fritsche Neto, 2015).

Given its economic importance, maize is grown on all continents, including temperate and tropical climate zones. In Brazil, this grain is grown in most of the territory, distributed in two harvests. From 2008/2009 on, the volume produced in the offseason crop exceeded that of the summer harvest, when farmers from the main producing regions started adopting the double-cropping (harvest/offseason crop) of soybean and maize, which contributed significantly to increase domestic production (CONAB, 2019).

Even though the maize supply chain has experienced major technological advances over the last years, the average national yield is considered low in relation to the biological potential of the crop. However, there is no doubt about the increase in yield experienced over the past four decades as a result of improved growing conditions and genetic progress, which are the result of works conducted by the breeding programs.

Hence, these programs have been focused on meeting the demands of farmers from each region, primarily with the goal of reaching new levels of productivity, leading to the adoption of strategies that enable maximization of genetic gains without, however, compromising the genetic variability of populations (Hallauer et al., 2010).

The Reciprocal Recurrent Selection (RRS), initially proposed by Comstock et al. (1949), stands out among the techniques used in population breeding. In accordance with the description by Souza Junior and Pinto (2000), in this study, genotypes of two populations are evaluated in crosses, and the ones with the best performance are recombined among themselves. This procedure allows improving, simultaneously, the populations per se and the interpopulation hybrid (IH).

Within this approach, the Universidade Estadual do Norte Fluminense Darcy Ribeiro
(UENF) has maintained, over the past two decades, a full-sib reciprocal recurrent selection (FSRRS) program in maize. This program has played a major role in regional development, as it is the only common maize breeding program in the state of Rio de Janeiro (Tardin et al., 2007; Cunha et al., 2012; Berilli et al., 2013).

Considering the long-term importance of recurrent selection, it is of great value to monitor the variability in work populations and the genetic gain obtained in each selection cycle. In Brazil, however, there is a gap with respect to this information, as available results in the literature consider only one or a few selection cycles, which leads to long-term studies, especially with respect to genetic progress and dynamics of components of variance throughout the different selection cycles.

The purpose of this study was to evaluate the development of the Piranão and CIMMYT populations throughout ten FSRRS cycles, in terms of genetic progress, and to verify the occurrence of heterosis among populations and its magnitude.

\section{Material and methods}

\section{Plant materials}

The plant material used for the study was developed in the Maize Breeding Program of the Universidade Estadual do Norte Fluminense Darcy Ribeiro. They are genotypes maintained by the Institution, and which comprise ten cycles of fullsib reciprocal recurrent (FSRRS) families (between the $6^{\text {th }}$ and $15^{\text {th }}$ cycles), developed according to the methodology proposed by Hallauer and Ebehart (1970), with some modifications.

Each of the ten selection cycles is represented by three genotypes: Piranão genotypes, CIMMYT genotypes, and interpopulation hybrids, totaling 30 genotypes.

Type of grain was the phenotypic marker used to distinguish the two heterotic populations used in RRS. The CIMMYT populations belong to the Flint heterotic group, whereas the Piranão populations, belong to the Dent heterotic group.

\section{Evaluation trials}

Evaluation trials were conducted in the summer harvests of the 2016/17 and 2017/18 crop year in the municipality of Campos dos Goytacazes, 
Rio de Janeiro State, Brazil, and in the municipality of Itaocara, Rio de Janeiro State, establishing four evaluation environments.

Genotype means were obtained from an alpha-lattice design trial (resolvable incomplete blocks) configuration $14 \times 20$, being $\mathrm{v}=280$ treatments; $k=14$ plots; and $n=20$ blocks with four replicates, totaling 4480 experimental units. The experimental design and the 280 genotypes were used for obtaining the adjusted means in the recovery of interblock information; but only the adjusted means of the 30 genotypes already mentioned will be considered in this work.

Plots were comprised of a $3 \mathrm{~m}$-long row, with a $0.90 \mathrm{~m}$ - inter-row spacing and $0.20 \mathrm{~m}$ between plants within the row. Three seeds were sown per hole and, at 21 days after emergency, thinning was performed, leaving one plant per hole, resulting in a final population of 55.5 thousand plants per hectare.

\section{Traits evaluated}

The following traits were evaluated: prolificacy (PR), obtained by dividing the number of ears by the stand of each experimental unit; husked ear weight (EW), obtained by weighing all the husked ears of the plots; and grain yield (GY), adjusted to $13 \%$ moisture and converted to kg.ha ${ }^{-1}$.

\section{Statistical analysis}

The observations collected for these traits were initially submitted to individual analysis of variance, and, after testing the homogeneity of variances, as suggested by Pimentel Gomes (2009), a joint analysis was conducted taking into account the four environments for the EW and GY characters and two environments (Environment 1 and Environment 3) for the PR character, as written in the following statistical model:

$Y_{i j k l}=\mu+b_{k(j)}+r_{j}+a_{l}+g_{i}+a g_{l i}+e_{i j k l}$ (Eq. 1)

Where $\mu$ is the overall mean; $b_{k(j)}$ is the random effect of block $\mathrm{j}$ on repetition $\mathrm{i} \sim$ NID $(0$, $\left.\sigma^{2} b\right) ; r_{j}$ is the random repetition effect; $a_{1}$ is the fixed effect of the k-th environment; $g_{i}$ is the random effect of genotype $\mathrm{i} \sim \operatorname{NID}\left(0, \sigma^{2} \mathrm{~g}\right)$; $\mathrm{ag}_{\mathrm{li}}$ is the effect of genotype $\mathrm{i}$ interaction on environment $\mathrm{k} \sim$ NID $\left(0, \sigma^{2} \mathrm{ga}\right)$; and $\mathrm{e}_{\mathrm{ijk}}=$ experimental error $\sim \operatorname{NID}\left(0, \sigma^{2}\right)$.

In the joint analysis, the environmental effect was considered as fixed, since the evaluation environments do not represent the totality of the edaphoclimatic conditions of the North and Northwest of Rio de Janeiro State. The genotype effects were considered as random, since the cycles were sampled over 20 years of the program.

The results were submitted to joint analysis of variance for the four environments by means of the PROC MIXED procedure of SAS version 9.3 (SAS INSTITUTE, 2011), applying the type III method, which resulted in "Least Square Means" or adjusted means. This analysis is the most relevant for alphalattice design experiments, as it enables the recovery of interblock information, which is seen as more adequate by Ramalho et al. (2012).

In the estimation of genetic progress, the means were submitted to simple linear regression, in which the selection cycles were considered as independent variable $(\mathrm{x}=6,7, \ldots, 15)$ and the PR, EW, and GY characters as dependent variable. From the resulting coefficients $\left(b_{1}\right.$ and $\left.b_{0}\right)$, the genetic progress for the traits mentioned was calculated from the following equation:

$$
\left.\Delta G(\%)=\left(\frac{b_{1}}{b_{0}}\right) \times 100 \quad \text { (Eq. } 2\right)
$$

In which: $\Delta \mathrm{G}$ : genetic gain; $\mathrm{b}_{1}$ : is the linear regression coefficient estimation; $b_{0}$ : corresponds to the intercept.

Considering the four environments, the relative heterosis parameter as well as the heterobeltiosis parameter were calculated by using the adjusted means, throughout the ten selection cycles, according to the expression presented by (Falconer and Mackay, 1996):

\section{Relative heterosis}

$$
H_{M P}(\%)=\left(\frac{\overline{I H}-\overline{M P}}{\overline{M P}}\right) x 100 \quad \text { (Eq. 3) }
$$

In which: $\mathrm{H}_{\mathrm{mp}}=$ relative heterosis; $\mathrm{IH}=$ mean of the interpopulation hybrid; MP = mean of the parents.

\section{Heterobeltiosis}

$$
H_{S P}=\left(\frac{\overline{H I}-\overline{S P}}{\overline{S P}}\right) \times 100 \quad \text { (Eq. 4) }
$$

In which: $\mathrm{H}_{\mathrm{ps}}=$ heterobeltiosis; $\mathrm{IH}=$ mean of the interpopulation hybrid; $\mathrm{SP}=$ superior population. 


\section{Results and discussion}

\section{Analysis of variance}

Table 1 displays the estimations and significance of the mean squares of the joint analysis, as well as the means, coefficients of variation, and efficiency of the lattice for the PR, EW, and GY characters.

The alpha-lattice design and adjusted means were efficient for the PR (106\%), EW (145\%), and GY $(140 \%)$ characters. Moreover, there was a good control of the experimental conditions expressed in the coefficients of variation, which were between 14.34 and $21.60 \%$ (Table 1). These values are close to the ones practiced in the maize crop trials and lower than those described by Cunha et al. (2012) and Galvão et al. (2015), given that, being quantitative characters, they are naturally highly influenced by environmental conditions.

On the basis of the coefficients of variation, the municipality of Campos dos Goytacazes presented greater precision when conducting maize trials in comparison with the environments of the municipality of Itaocara (2019/17 and 2017/18 crop year).

Table 1. Overall joint analysis of variance for PR (ENV1 and ENV3), EW, and GY (ENV1, ENV2, ENV3, and ENV4) traits evaluated in 280 genotypes. Campos dos Goytacazes and Itaocara, Rio de Janeiro State, Brazil.

\begin{tabular}{cccccccccc}
\hline \multirow{2}{*}{ SOV } & \multicolumn{3}{c}{ PR } & \multicolumn{3}{c}{ EW } & \multicolumn{3}{c}{ GY } \\
\cline { 2 - 10 } & DF & MS & F & DF & MS & F & DF & MS & F \\
\hline Environment & 1 & 19.57 & $359.6^{* *}$ & 3 & $79.2 \times 10^{6}$ & $95.60^{* *}$ & 3 & $276.6 \times 10^{6}$ & $48.59^{* *}$ \\
\hline Entry (adj) & 278 & 0.115 & $2.93^{* *}$ & 279 & $1.22 \times 10^{6}$ & $6.00^{* *}$ & 279 & $7.93 \times 10^{6}$ & $6.13^{* *}$ \\
\hline Entry*Env & 278 & 0.046 & 1.19 NS & 836 & $3.38 \times 10^{*}$ & $1.66^{* *}$ & 836 & $2.21 \times 10^{6}$ & $1.70^{* *}$ \\
\hline Block/Rep (adj) & 154 & 0.051 & $1.3^{\text {NS }}$ & 312 & $6.8 \times 10^{5}$ & $3.37^{* *}$ & 312 & $4.69 \times 10^{6}$ & $3.63^{* *}$ \\
\hline Error & 1456 & 0.039 & & 2890 & $2.0 \times 10^{5}$ & & 2890 & $1.29 \times 10^{6}$ & \\
\hline Mean & & 1.25 & & & 2,500 & & & 5,990 & \\
\hline CV (\%) & & 15.86 & & & 18.06 & & & 19.00 & \\
\hline LE (\%) & & 106 & & & 145 & & & 140 & \\
\hline & MSe & Mean & CV (\%) & MSe & Mean & CV (\%) & MSe & Mean & CV (\%) \\
\hline ENV1 & 0.046 & 1.35 & 16.03 & $1.39 \times 10^{5}$ & 2245 & 16.65 & $1.03 \times 10^{6}$ & 5663 & 17.94 \\
\hline ENV2 & - & - & - & $2.21 \times 10^{5}$ & 2350 & 20.02 & $1.45 \times 10^{6}$ & 5675 & 21.23 \\
\hline ENV3 & 0.031 & 1.15 & 15.37 & $1.90 \times 10^{5}$ & 2833 & 15.41 & $1.11 \times 10^{6}$ & 6673 & 15.76 \\
\hline ENV4 & - & - & - & $3.27 \times 10^{5}$ & 2584 & 22.15 & $1.67 \times 10^{6}$ & 5965 & 21.71 \\
\hline$>$ MSe/<MSe & & 1.5 & & & 2.1 & & & 1.6 &
\end{tabular}

NS: non-significant; **: significant at level $1 \%$ of probability by the F test. PR: Prolificacy; EW: husked ear weight; GY: Grain Yield; DF: Degree of Freedom; MS: Mean Square; F: F Test; ENV: Environment; Gen: Genotype; Rep: Repetition; CV: Coefficient of Variance; ENV1: Campos dos Goytacazes (crop year 2016/17); ENV2: (crop year 2016/17); ENV3: Campos dos Goytacazes (crop year 2017/18); ENV4: Itaocara (crop year 2017/18); LE (\%) Lattice Efficiency; MSe: Mean Square error.

\section{Genetic progress}

The adjusted means, with four environments and ten cycles of reciprocal recurrent selection for the PR, EW, and GY characters, are displayed in Table 2. It should be emphasized that, in programs of reciprocal recurrent selection, there are indirect gains, based on the evolution of traits in the populations per se, and direct gains, measured directly in the performance of the interpopulation hybrid obtained at each selection cycle (Moll et al., 1994; Hallauer and Carena, 2009).
The means for the PR character ranged from 1.03 to 1.39 , in the CIMMYT population cycles (Figure 1a); 1.04 to 1.75 , in the Piranão population cycles (Figure 1c); and 1.13 to 1.57 , in the interpopulation hybrids cycles (Figure 1b). The means given for the ten selection cycles for interpopulation hybrids were superior to the values for both populations per se. By means of the angular coefficient, it can be confirmed that there was an average increase of $0.036,0.032$, and 0.040 ears.plant ${ }^{-1}$.cycle $^{-1}$, significant values by the $t$ test at $1 \%$ probability (Table 2 ). 
Table 2. Adjusted means for Prolificacy (PR), Husked Ear Weight (EW), and Grain Yield (GY) in maize obtained in the municipalities of Campos dos Goytacazes and Itaocara in 2016/17 and 2017/18 crop year.

\begin{tabular}{|c|c|c|c|c|c|c|c|c|c|c|c|c|c|c|}
\hline \multirow{2}{*}{ Genotypes } & \multicolumn{11}{|c|}{ Selection Cycles } & \multicolumn{3}{|c|}{$\begin{array}{l}\text { Regression } \\
\text { Coefficients }\end{array}$} \\
\hline & $\mathrm{C} 6$ & $\mathrm{C} 7$ & $\mathrm{C} 8$ & $\mathrm{Cg}$ & $\mathrm{C} 10$ & C11 & $\mathrm{C} 12$ & $\mathrm{C} 13$ & C14 & $\mathrm{C} 15$ & Mean & $b_{0}$ & $\mathbf{b}_{1}$ & $\mathbf{R}^{2}$ \\
\hline \multicolumn{15}{|c|}{ PR (ear.plant-1) } \\
\hline Piranão & 0.97 & 1.08 & 1.15 & 1.24 & 1.27 & 1.33 & 1.43 & 1.32 & 1.34 & 1.27 & 1.24 & 0.86 & $0.036^{* *}$ & 0.64 \\
\hline CIMMYT & 1.01 & 1.01 & 0.98 & 1.11 & 1.09 & 1.17 & 1.14 & 1.23 & 1.21 & 1.29 & 1.12 & 0.78 & $0.032^{* *}$ & 0.90 \\
\hline Piranão x CIMMYT & 1.12 & 1.14 & 1.16 & 1.31 & 1.31 & 1.53 & 1.23 & 1.46 & 1.46 & 1.45 & 1.32 & 0.89 & $0.040^{* *}$ & 0.66 \\
\hline \multicolumn{15}{|c|}{ EW (g.plot-1) } \\
\hline Piranão & 1851 & 1607 & 1869 & 1765 & 2019 & 2173 & 2284 & 2126 & 2159 & 2192 & 2073 & 1372 & $60.2^{* \star}$ & 0.68 \\
\hline CIMMYT & 1710 & 1609 & 1859 & 1944 & 1597 & 1603 & 1352 & 1687 & 1916 & 1881 & 1698 & 1645 & $6.73^{\mathrm{NS}}$ & 0.01 \\
\hline Piranão x CIMMYT & 2477 & 2425 & 2687 & 2177 & 2483 & 3160 & 2693 & 2847 & 2972 & 2929 & 2690 & 1986 & $66.5^{*}$ & 0.45 \\
\hline \multicolumn{15}{|c|}{ GY (kg.ha-1) } \\
\hline Piranão & 4241 & 3728 & 4334 & 4173 & 4403 & 4816 & 5280 & 4878 & 5031 & 5191 & 4609 & 3072 & $146.3^{* *}$ & 0.77 \\
\hline CIMMYT & 3743 & 3424 & 4210 & 4435 & 3833 & 3589 & 3116 & 3997 & 4546 & 4253 & 3915 & 3454 & $44.0^{\mathrm{NS}}$ & 0.08 \\
\hline Piranão x CIMMYT & 5944 & 5588 & 6308 & 5086 & 5875 & 7683 & 6738 & 6904 & 6947 & 6958 & 6523 & 4590 & $173.0^{*}$ & 0.44 \\
\hline \multicolumn{15}{|c|}{ Heterosis (\%) } \\
\hline $\mathrm{H}_{\mathrm{MP}}$ & 48.9 & 56.3 & 47.7 & 18.2 & 42.7 & 82.8 & 60.5 & 55.6 & 45.1 & 47.4 & 50.5 & & & \\
\hline $\mathrm{H}_{\mathrm{sp}}$ & 40.2 & 49.9 & 45.5 & 14.7 & 33.4 & 59.5 & 27.6 & 41.5 & 38.1 & 34.0 & 38.4 & & & \\
\hline
\end{tabular}

NS: non-significant; **: significant at level 1\% of probability by the t test. PR: Prolificacy; EW: Ear Weight; GY: Grain Yield;

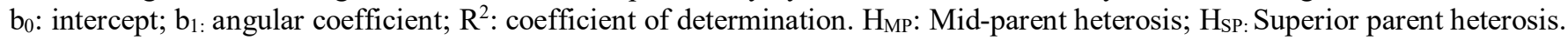

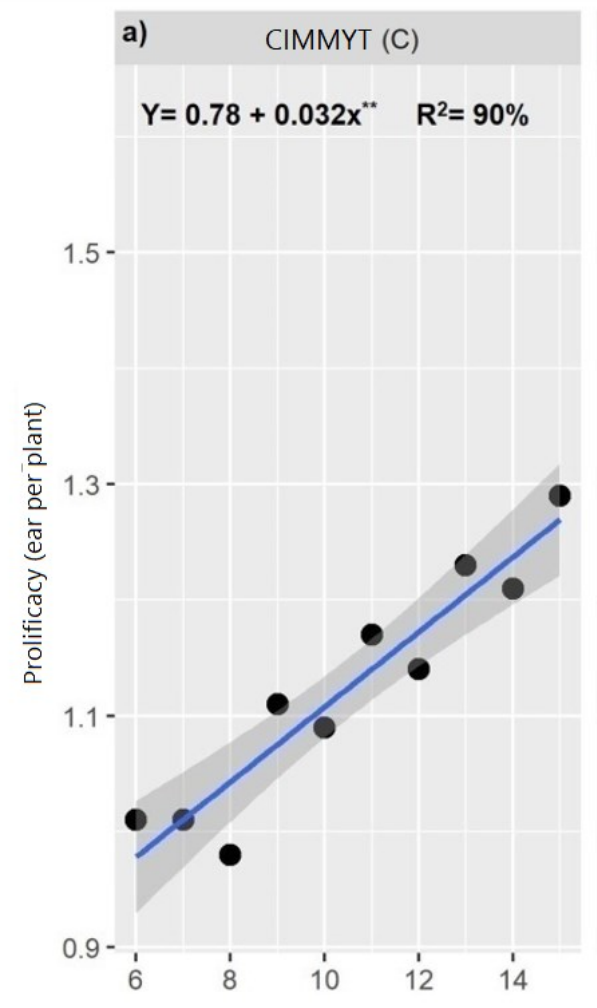

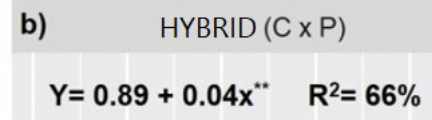

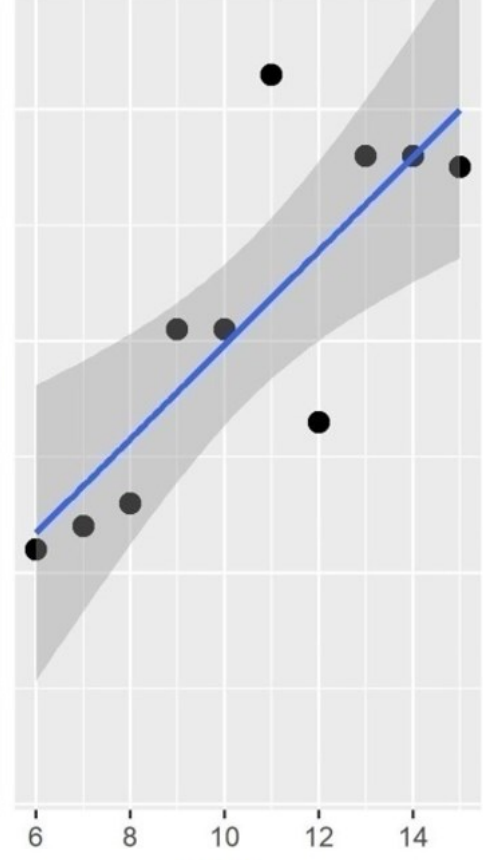

Cycles

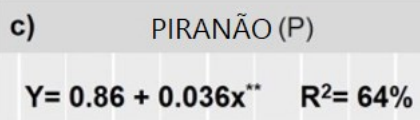

$Y=0.86+0.036 x^{* *} \quad R^{2}=64 \%$

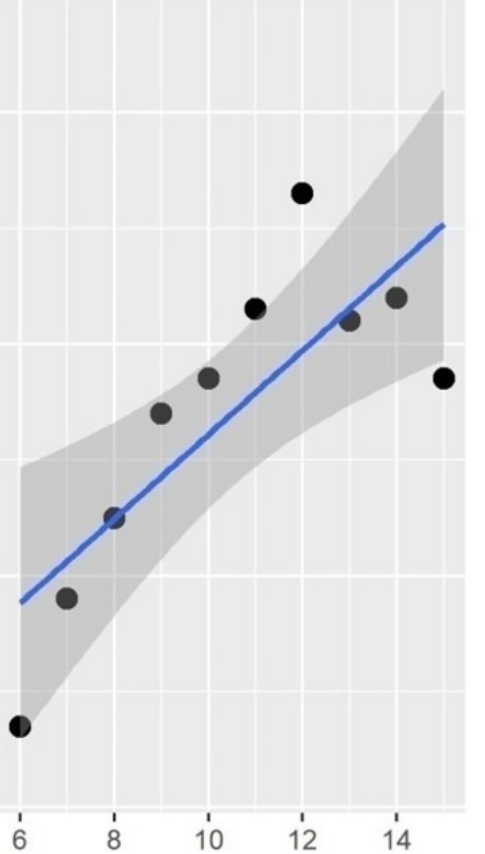

Figure 1. Linear regression for CIMMYT population (a), interpopulation hybrid (b), and Piranão population (c) between the dependent variable prolificacy $(\mathrm{y})$ and the independent variable number of cycles $(\mathrm{x})$. Campos dos Goytacazes and Itaocara, Brazil (crop year 2016/17-2017/18). 
The above results correspond to 4.19, 4.10, and $4.49 \%$ gain per selection cycle regarding the intercept $\left(\mathrm{b}_{0}\right)$, calculated for the Piranão population, CIMMYT population, and interpopulation hybrids, respectively. The increases are significantly higher than the ones described by Reis et al. (2009), who obtained $0.7 \%$, and lower than the one recommended by Souza Júnior and Pinto (2000), which was an $11.8 \%$ increase per cycle.

A number of authors describe the correlation between the PR and GY characters for maize crop, which suggests that the increase in the first is generally focused on an increase in the second (Paterniani and Miranda Filho, 1987; Lima Neto and Souza Junior, 2009; Câmara et al., 2007; Candido and Andrade, 2008; Baretta et al., 2016). However, it has to be said that other attributes of ears are also positively correlated with yield, such as weight and length. This second component, in appropriate pollination and fertilization conditions, results in a higher number of grains per ear and, consequently, a higher grain yield.

In addition, prolificacy is an essential condition for the implementation of RRS, and it is correlated to other attributes, like productive stability of genotypes and greater tolerance to water stress condition (Lima Neto and Souza Junior, 2009). Hence, this character is of great importance, since short periods of summer are very common in tropical regions and in second harvest crops (offseason), in which the availability of water is a limiting factor when compared with the first harvest (summer harvest) (Souza Júnior et al., 2010).

EW means ranged from 1.607 to $2.284 \mathrm{~kg} \cdot \mathrm{ha}^{-}$ ${ }^{1}$ between the Piranão population cycles; from 1.597 to $1.944 \mathrm{~kg}^{-h^{-1}}$ in the CIMMYT populations; and from 2.177 to $3.160 \mathrm{~kg} \cdot \mathrm{ha}^{-1}$ between the interpopulation hybrids. The yield increase was not only significant for the CIMMYT population, which obtained $a b_{1}$ of 6.73 , whereas the Piranão and the hybrid had a significant $b_{1}$ of 60.2 and 66.5, respectively (Table 2).

The response pattern for GY (Figure 3) is similar to the one for EW (Figure 2), as these traits are highly correlated (Lopes et al., 2007). The grain yield character is the most vital for maize crop; consequently, it is the main goal of breeding programs, both for public institutions and private sector (Lima Neto and Souza Junior, 2009; Hallauer et al., 2010).

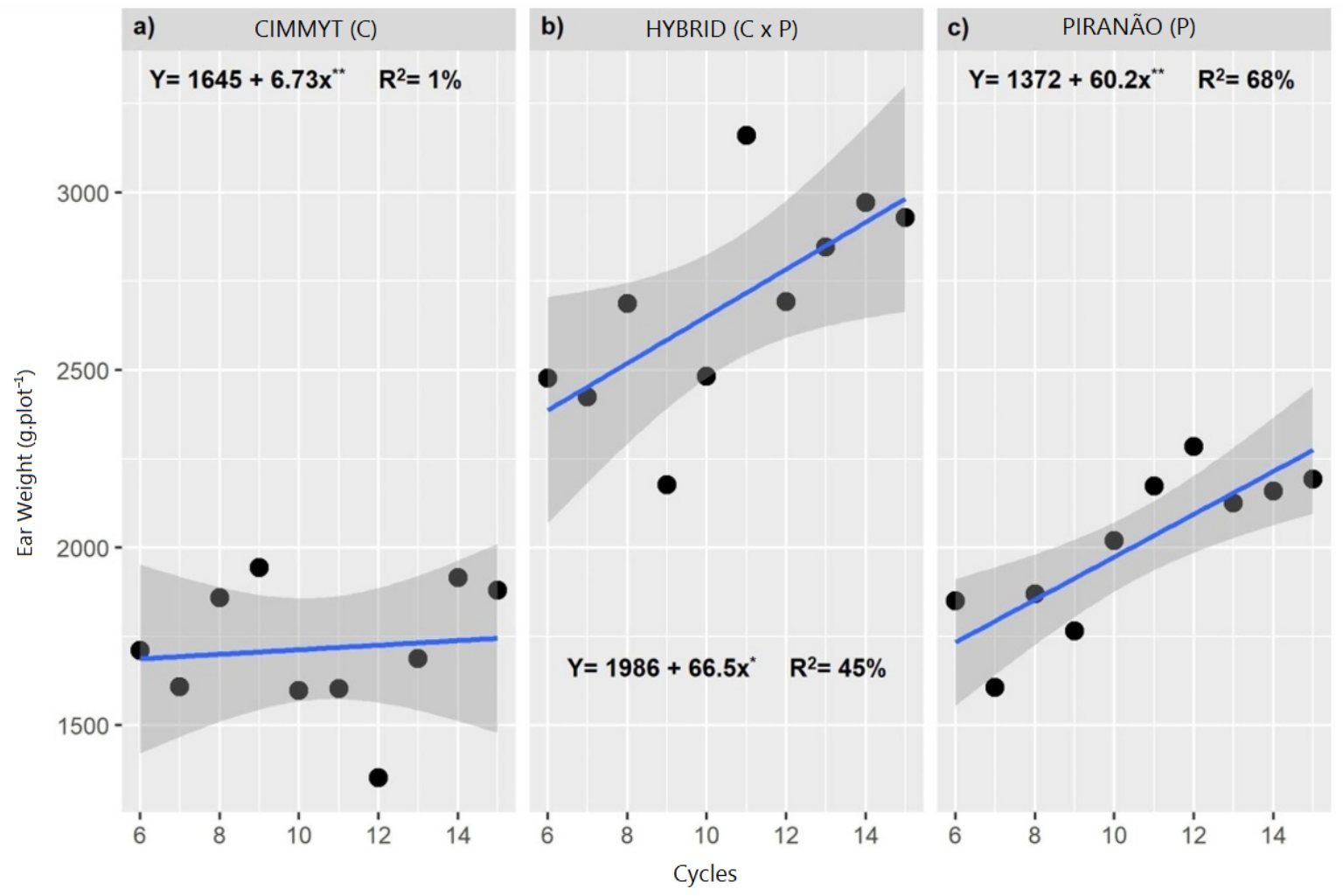

Figure 2. Linear regression equation for CIMMYT population (a), interpopulation hybrid (b), and Piranão population (c) between the dependent variable ear weight (y) and the independent variable number of cycles (x). Campos dos Goytacazes and Itaocara, Brazil (crop year 2016/17-2017/18). 
The GY means in the interpopulation hybrids (Piranão Cn x CIMMYT Cn) were 28\% and 38\% higher than the performance obtained by the two populations per se Piranão and CIMMYT, respectively (Table 2). It should be pointed out that the interpopulation hybrid mean, throughout the cycles, is higher than the Brazilian one in the last harvests (CONAB, 2019).

Regarding the national mean yield, it is low in comparison to the good results achieved in technified crops. This is mainly justified by the differences in farming systems and technological levels adopted, for advances in this supply chain are not uniformly occurring for all regions (Duarte and Kappes, 2015).

It can be seen that CIMMYT populations (Figure 3a) presented lower performance than other genotype groups and production instability along the cycles. A number of authors report that, when it comes to reciprocal recurrent selection, it is common to obtain little or no gain in one of the populations (Keeratinijakal and Lamkey, 1993; Raposo and Ramalho, 2004; Hallauer Carena, 2009; Reis et al., 2013). For the CIMMYT populations, it was verified an increase of $44 \mathrm{~kg} \cdot \mathrm{ha}^{-1} \cdot \mathrm{cycle}^{-1}$ of selection and $22 \mathrm{~kg} \cdot \mathrm{ha}^{-1} \cdot$ year $^{-1}$, of which values are not significant by the $t$ test at $1 \%$ probability and an $\mathrm{R}^{2}$ of 0.08 (Figure 3 ). Based on the estimates, it was calculated $0.41 \%$ of global gain along the ten selection cycles, proving to be extremely low.

With regard to the Piranão populations, there was an increase of $146 \mathrm{~kg} \cdot \mathrm{ha}^{-1} \cdot$ cycle $^{-1}$ and $72 \mathrm{~kg} \cdot \mathrm{ha}$ ${ }^{1}$.year, being significant by the $\mathrm{t}$ test at $1 \%$ probability, indicating satisfactory genetic progress. With respect to the intercept, $4.75 \%$ gain per selection cycle was observed (Figure $3 \mathrm{c}$ ). These results are similar to those of Ribeiro et al. (2016), who, along seven recurrent selection cycles in the UNB-2 population, obtained $3.74 \%$ increase in grain yield per selection cycle.

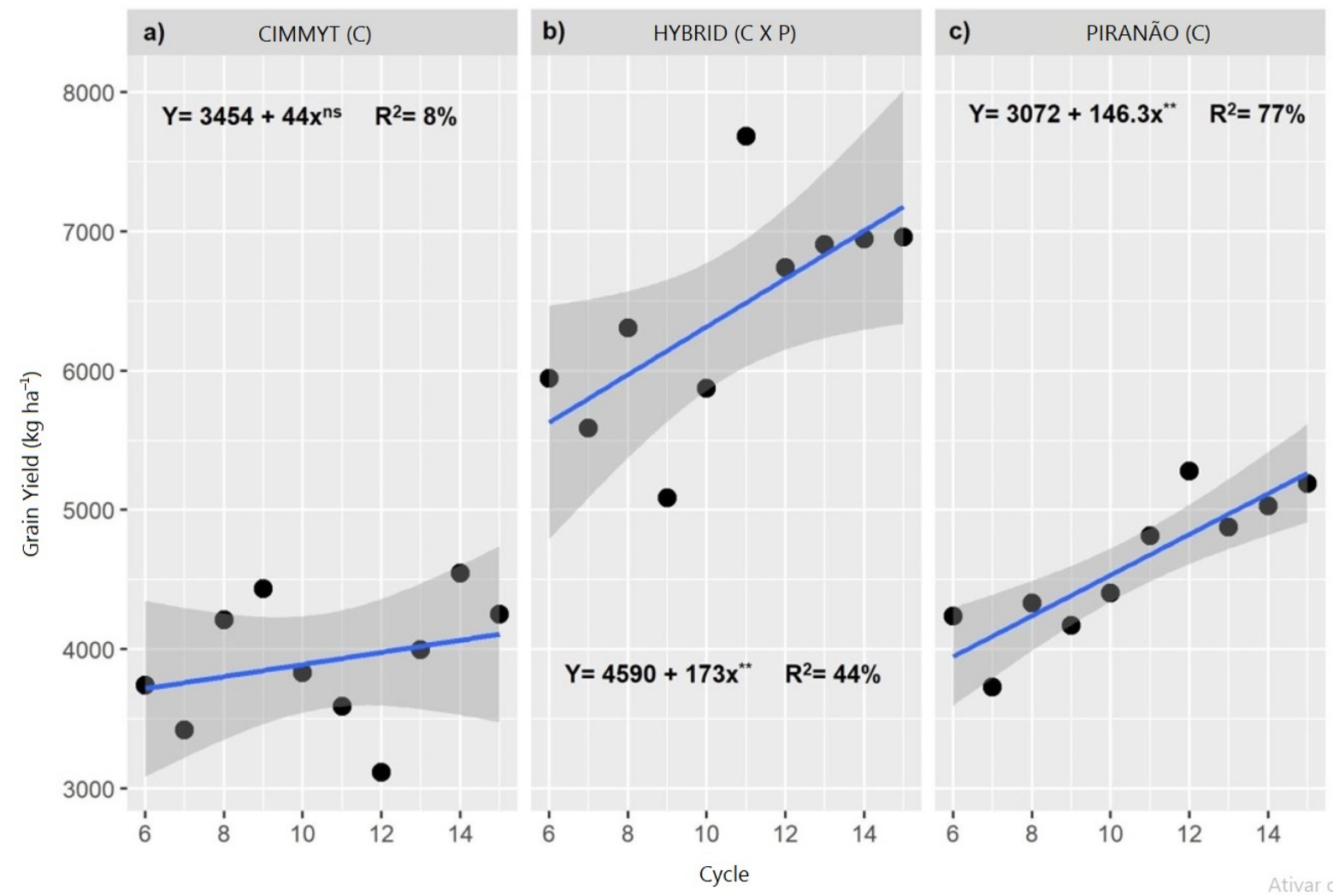

Figure 3. Linear regression equation for the CIMMYT population (a), interpopulation hybrid (b), and Piranão population (c) between the dependent variable grain yield (y) and the independent variable number of cycles $(\mathrm{x})$. Campos dos Goytacazes and Itaocara, Brazil (crop year 2016/17 - 2017/18). 
The interpopulation hybrid is defined by the cross of two improved populations after the end of each RRS cycle. The mean grain yield, along the cycles, was between $5.944 \mathrm{~kg} \cdot \mathrm{ha}^{-1}\left(\mathrm{C}_{6}\right)$ and 7.686 kg.ha ${ }^{-1}\left(\mathrm{C}_{11}\right)$ (Figure 3b), in which the eleventh showed the best performance with retraction in subsequent cycles. The $\mathrm{C}_{11}$ originated the UENF 506-11 hybrid, registered at the Ministry of Agriculture, Livestock, and Supply (in Portuguese, Ministério da Agricultura Pecuária e Abastecimento - MAPA) and made available to farmers in the state of Rio de Janeiro.

This hybrid has many desirable aspects and great potential for use on small properties, as it has good productive performance and low cost of acquiring seed. Hence, it is an appropriate input for crops located in areas known to be marginal for maize production, allowing increased yield and better profitability for farmers (Reis et al., 2009).

The direct gains in interpopulation hybrids were $171 \mathrm{~kg} \cdot \mathrm{ha}^{-1}$. cycle $^{-1}$, resulting in an annual gain of over $85 \mathrm{~kg} \cdot \mathrm{ha}^{-1}$. This represents $3.37 \%$ of genetic progress per selection cycle compared to $b_{0}(4590)$ (Figure $3 \mathrm{~b}$ ). The progress shown is higher than that observed in Brazil, which, in the past forty years, resulted in $38 \mathrm{~kg}^{-} \mathrm{ha}^{-1}$ of genetic progress per year, assuming that it is approximately $50 \%$ of the total increase measured (CONAB, 2019; Duvick, 2005).

Keeratinijakal and Lamkey (1993) reported a $6.95 \%$ increase per selection cycle in the grain yield of interpopulation hybrids from BSSS and $\mathrm{BSBC}_{1}$ populations after 11 RRS cycles. Similarly, Russell et al. (1992) obtained 4.9\% in the interpopulation hybrid from the cross between BS21 (R) x BS22 (R) populations during three selection cycles. Raposo et al. (2004) and Reis (2013) reported 5.7 and 4.5\% increases in grain yield, respectively, after three RRS cycles, in populations from simple hybrids.

\section{Heterosis and heterobeltiosis}

Heterosis is a relative parameter that indicates the hybrid superiority over the mean performance of the parents. A prominent and highly desirable aspect is that the reciprocal recurrent selection captures the heterotic effects by crossing individuals from two populations (Souza Júnior, 2011).
Based on the findings of this study, there were heterosis values, in relation to the parent mean, between $18.2 \%\left(\mathrm{C}_{9}\right)$ and $82.8 \%\left(\mathrm{C}_{11}\right)$ for the grain yield character throughout the ten selection cycles (Table 2). In general, mean heterosis close to $50 \%$ was observed, a value very close to that inferred in other works (Parra et al., 2010; Doná et al., 2012).

The establishment of heterosis values along the cycles proves that the genetic gains in interpopulation hybrids were provided exclusively by yield increases in populations per se, here leveraged by the Piranão populations, indicating that the additive effects of genes were significant for trait expression in this study.

With the advancement of RRS cycles, however, a gradual increase was expected in this respect, given that the different recombination cycles performed within each population would result in greater genetic distance between the two populations, thus capturing the non-additive effects of the genes, which is one of the conditions for heterosis to occur (Falconer and Mackay, 1996; Hallauer et al., 2010). However, there are reports of heterosis reduction with advancing RRS (Hallauer, 1977).

Because they are interpopulation hybrids, the results herein are considered of high magnitude and superior to the ones found by other authors, as stated by Faria et al. (2008), who verified $28 \%$ heterosis among $\mathrm{S}_{0} \mathrm{xS}_{0}$ hybrids in RRS in popcorn crop. Hallauer and Miranda Filho (1981) obtained mean heterosis of $19.5 \%$ from 1394 intervarietal crosses in maize.

In general, the magnitude of the heterosis in interpopulation hybrids is lower than that of inbred line hybrids, since, in crosses among broad-based or panmictic populations, most of the loci present intermediate allelic frequencies (Bernini, 2011). But this does not diminish the importance of this parameter in population breeding, since the use of interpopulation hybrids is of great value for market niches and, additionally, the populations present potential for inbred line extraction and hybrid synthesis (Garcia, 2009).

Heterobeltiosis, related to the performance of the $F_{1}$ hybrid with respect to the performance of the 
best parent, has particular importance, as the launch of new genotypes is only justified if the performance of the hybrid is considerably higher than that of its best performing parent. During the selection cycles, values ranging from $14.7 \%\left(C_{9}\right)$ to $59.5 \%\left(C_{11}\right)$ were found (Table 2).

On average, heterobeltiosis ranged around $38.4 \%$ along the recurrent selection cycles, significantly higher than that reported by Arias and Souza Junior (1998), and Ferreira et al. (2009). The $\mathrm{C}_{11}, \mathrm{C}_{7}$, and $\mathrm{C}_{8}$ cycles presented the highest values in this aspect, highlighting the $\mathrm{C}_{11}$ and $\mathrm{C}_{8}$, in which the value was driven by the excellent performance achieved by the IH in relation to the superior parent. Conversely, in $\mathrm{C}_{7}$, there was a low performance of Piranão 7, which was determinant for the expression of this behavior.

This information is relevant because, theoretically, the best performing cycles for heterosis and heterobeltiosis have the potential to be used in obtaining lines for hybrid synthesis.

\section{Conclusions}

The RRS does not ensure the performance improvement of both populations per se in a proportional way; however, it is efficient in delivering genetic gains for PR, EW, and GY characters in the interpopulation hybrid, including in long-term programs.

The results of heterosis and heterobeltiosis suggest a discrepancy between the parents, significantly increased throughout the cycles, because of the gains obtained by the Piranão parent and the stagnation of the CIMMYT parent.

There was an average increase of $171 \mathrm{~kg} \cdot \mathrm{ha}$ ${ }^{1}$.cycle ${ }^{-1}$ along the ten cycles for the interpopulation hybrid, suggesting viability of performing FSRRS, generating genetic gains in the short-, medium-, and long-term.

\section{References}

ARIAS, C.A.A.; SOUZA JÚNIOR, C.L. 1998. Variância genética e componentes de covariância relacionados à seleção recorrente intra e interpopulacional em milho (Zea mays L.). Genetics and Molecular Research, 21(4):1-8.

BARETTA, D.; NARDINO, M.; CARVALHO, I.R.; OLIVEIRA, A.C.; SOUZA, V.Q.; MAIA, L.C. 2016. Desempenho de genótipos de milho do Rio Grande do Sul utilizando modelos mistos. Científica, 44(3):403-411.

BERILLI, A.P.C.G.; PEREIRA, M.G.; TRINDADE, R.S.; COSTA, F.R. 2013. Response to the selection in the 11th cycle of reciprocal recurrent selection among full-sib families of maize. Acta Scientiarum, 35:435-441.

BERNINI, C.S. 2011. Avaliação agronômica e heterose de híbridos de populações $F_{2}$ de milho, visando nova alternativa para o estado de São Paulo. Thesis ( $\mathrm{PhD}$ in Agricultura Tropical e Subtropical). Instituto Agronômico, Campinas, 74p.

CÂMARA, T.M.M.; BENTO, D.A.V.; ALVES, G.F.; SANTOS, M.F.; MOREIRA, J.U.V. 2007. Parâmetros genéticos de caracteres relacionados à tolerância à deficiência hídrica em milho tropical. Bragantia, 66(4):595-603.

CANDIDO, L.S.; ANDRADE, J.A.C.; GARCIA, Q.F.; GONÇALVES, L.S.A.; AMARAL JÚNIOR, A.T. 2011. Seleção de progênies de meios-irmãos do composto Isanão VF-1 de milho na safra e safrinha. Ciência Rural, 41(6):947-953.

CONAB - Companhia Nacional de Abastecimento. 2019. Séries históricas. Available in: http://www.conab.gov.br/conteudos.php? $\mathrm{a}=1252 \& \mathrm{t}=2 \&$ Pagina_objcmscontedos $=3 \#$ A_objemsconte udos. 
COMSTOCK, R.E., ROBINSON H.F., HARVEY, P.H.A. 1949. Breeding procedure designed to make maximum use of both general and specific combining ability. Agronomy Journal, 41:360-367.

CUNHA, K.S.; PEREIRA, M.G.; GONÇALVES, L.S.A.; BERILLI, A.P.C.G. 2012. Full-sib reciprocal recurrent selection in the maize populations Cimmyt and Piranão. Genetics and Molecular Research, 11(3):3398-3408.

DONÁ, A.A.; MIRANDA, G.V.; LIMA, R.O.; CHAVES, L.G.; GAMA, E.E.G. 2012. Genetic Parameters and Predictive Genetic Gain in Maize with Modified Recurrent Selection Method. Chilean Journal of Agricultural, 72(1):33-39.

DUARTE, A.P.; KAPPES, C. 2015. Evolução dos sistemas de cultivo de milho no Brasil. Informações Agronômicas, 152:15-18.

DUVICK, D.N. 2005. The contribution of breeding to yield advances in maize (Zea mays L.). Advances in Agronomy, 86:83-145.

FALCONER, D.S.; MACKAY, T.F.C. 1996. Introduction to quantitative genetics. 4.ed. Edinburgh: Longman Group Limited, 464p.

FARIA, V.R.; VIANA, J.M.S.; SOBREIRA, F.M.; SILVA, A.C. 2008. Seleção recorrente recíproca na obtenção de híbridos interpopulacionais de milho-pipoca. Pesquisa Agropecuária Brasileira, 43(12):1749-1755.

FERREIRA, E.A.; PATERNIANI, M.E.A.G.Z.; DUARTE, A.P.; GALLO, P.B.; SAWAZAKI, E.; AZEVEDO FILHO, J.A.; GUIMARÃES, P.S. 2009. Desempenho de híbridos top crosses de linhagens S3 de milho em três locais do Estado de São Paulo. Bragantia, 68(2):319-327.

GALVÃO, K.S.C.; RAMOS, H.C.C.; SANTOS, P.H.A.D.; ENTRINGER, G.C.; VETTORAZZI, J.C.F.; PEREIRA, M.G. 2015. Functional molecular markers (EST-SSR) in the full-sib reciprocal recurrent selection program of maize (Zea mays L.). Genetics and Molecular Research, 14:7344-7355.

GARCIA, F.Q. 2009. Potencial das populações Isanão-VF1 e Isanão-VD1 para seleção recorrente recíproca. Thesis (PhD inAgronomy) Universidade Estadual Paulista, Ilha Solteira, 89p.

HALLAUER, A.R. 1977. Four cycles of reciprocal full-sib selection. Ames: Iowa State Univ., p.11-13.

HALlAUER, A.R.; CARENA, M.J. 2009. Maize breeding. In: 'Handbook of plant breeding: cereals'. (Ed. MJ Carena). pp. 3-98. Springer, New York.

HALlAUER, A.R.; CARENA, M.J.; MIRANDA FILHO, J.B. 2010. Quantitative Genetics in Maize Breeding. Springer, New York. 663p.

HALLAUER, A.R.; EBERHART, S.A. 1970. Reciprocal full-sib selection. Crop Science, 10(3):315-316.

HALLAUER, A.R.; MIRANDA FILHO, J.B. 1981. Quantitative genetics in maize breeding. Press, Iowa State Univ. 168p.

KEERATINIJAKAL, V.; LAMKEY, K.R. 1993. Responses to reciprocal recurrent selection in BSS and BCSB1 maize populations. Crop Science, 33(1):73-73.

LIMA NETO, F.P.; SOUZA JÚNIOR, C.L. 2009. Number of recombinations and genetic properties of a maize population undergoing recurrent selection. Scientia Agrícola, 66(1):52-58. 
LOPES, S.J.; LUCIO, A. D.; STORK, L.; DAMO, H.P.; BRUM, B.; SANTOS, V.J. 2007. Relações de causa e efeito em espigas de milho relacionadas aos tipos de híbridos. Ciência Rural, 37(6):15361542.

MOLL, R.H.A.; JACKSON, W.; MIKKELSEN, R.L. 1994. Recurrent Selection for Maize Grain Yield: Dry Matter and Nitrogen Accumulation and Partitioning Changes. Crop Science, 34:874-881.

MORO, G.V.; FRITSCHE-NETO, R. 2015. Importância e usos do milho no Brasil. In: 'Milho do plantio à colheita'. (Eds. A Borém, JCC Galvão, MA Pimentel) pp. 9-24. Editora UFV, Viçosa.

PARRA, J.R.; RIVERA, M.M.M.; GONZÁLEZ, J.J.S.; LARIOS, L.L.C.; MÁRQUES, M.R.; DÍAZ, R.J.L. 2010. Heterosis and combining ability among maize narrow-base populations. Maydica, 55:75- 83.

PATERNIANI, E.; MIRANDA FILHO, J.B. 1987. Melhoramento de populações. In: 'Melhoramento e produção de milho'. (Eds. E Paterniani, GP Viegas) v.1. p. 217-264. Fundação Cargill, Campinas.

PIMENTEL-GOMES, F. 2009. Curso de estatística experimental. 15. ed., Fealq, Piracicaba. 451p.

RAMALHO, M.A.P.; FERREIRA, D.F.; OLIVEIRA, A.C. 2012. Experimentação em genética e melhoramento de plantas. 3. ed. UFLA, Lavras, 328p.

RAPOSO, F.V.; RAMALHO, M.A.P.; RIBEIRO, P.H.E. 2004. Alterations in heterosis of maize populations derived from single-cross hybrids after a reciprocal recurrent selection. Crop Breeding and Applied Biotechnology, 4:74-80.

REIS, M.C.; GUEDES, F.L.; ABREU, G.B.; SOUZA, J.C. 2013. Reciprocal recurrent selection in maize enhances heterosis and ears yield. Euphytica, 191:217-222.

REIS, M.C.; SOUZA, J.C.; RAMALHO, M.A.P.; GUEDES, F.L.; SANTOS, P.H.A.D. 2009. Progresso genético com a seleção recorrente recíproca para híbridos interpopulacionais de milho. Pesquisa Agropecuária Brasileira, 44(12):1667-1672.

RIBEIRO, R.M.; AMARAL JÚNIOR, A.T.; PENA, G.F.; VIVAS, M.; KUROSAWA, R.F.N.; GONCALVES, L.S.A. 2016. Effect of recurrent selection on the variability of the UENF-14 popcorn population. Crop Breeding and Applied Biotechnology, 16:123-131.

SAS INSTITUTE INC. 2011. SAS/STAT software 9.3. SAS Institute Inc. Cary, NC, USA.

SOUZA JÚNIOR, C.L.; BARRIOS, S.C.L.B.; MORO, G.V. 2010. Performance of maize single-crosses developed from populations improved by a modified reciprocal recurrent selection. Scientia Agricola, 67(2):198-205.

SOUZA JÚNIOR, C.L. 2011. Cultivar development of allogamous crops. Crop Breeding and Applied Biotechnology, 11:8-15.

SOUZA JÚNIOR, C.L.; PINTO, R.M.C. 2000. Responses to a short-term reciprocal recurrent selection procedure in maize. Maydica, 45(1):21-28.

TARDIN, F.D.; PEREIRA, M.G.; GABRIEL, A.P.C.; AMARAL JÚNIOR, A.T.; SOUZA FILHO, G.A. 2007. Selection index and molecular markers in reciprocal recurrent selection in maize. Crop Breeding and Applied Biotechnology, 7:225-233. 